\title{
Pengaruh Suhu, Pemupukan K dan N Terhadap Pertumbuhan Tanaman Padi Inpari 30 (Oryza sativa $\mathbf{L}$.)
}

(Effect of Temperature, K and N Fertilization on Growth of Rice Inpari 30

(Oryza sativa L.))

\author{
Husna $^{1}$, Bakhtiar ${ }^{1}$, Cut Nur Ichsan* \\ ${ }^{1}$ Jurusan Agroteknologi, Fakultas Pertanian, Universitas Syiah Kuala \\ *Corresponding author: cut_nurichsan@unsyiah.ac.id
}

\begin{abstract}
Abstrak. Penelitian ini bertujuan untuk mengetahui pengaruh suhu, pemupukan $\mathrm{K}$ dan $\mathrm{N}$ terhadap pertumbuhan tanaman padi Inpari 30. Penelitian dilaksanakan di Rumah Kaca 1 dan Rumah Kaca 2 Fakultas Pertanian Universitas Syiah Kuala yang berlangsung dari bulan November 2020 - Februari 2021. Rancangan yang digunakan adalah Split-split Plot pola RAK Faktorial 2 × 2 × 3 dengan 3 ulangan sehingga terdapat 12 kombinasi perlakuan dan 36 satuan percobaan dengan total 108 unit percobaan. Faktor yang diteliti adalah suhu (T) sebagai petak utama yang terdiri dari dua taraf, yaitu $\mathrm{T}_{1}\left(28-32^{\circ} \mathrm{C}\right)$ dan $\mathrm{T}_{2}\left(33-37^{\circ} \mathrm{C}\right)$, pemupukan $\mathrm{K}(\mathrm{K})$ sebagai anak petak yang terdiri dari dua taraf, yaitu $\mathrm{K}_{1}\left(100 \mathrm{~kg} \mathrm{~K} \mathrm{ha}^{-1}\right)$ dan $\mathrm{K}_{2}\left(150 \mathrm{~kg} \mathrm{~K} \mathrm{ha}^{-1}\right)$. dan pemupukan $\mathrm{N}(\mathrm{N})$ sebagai anak-anak petak yang terdiri dari tiga taraf, yaitu $\mathrm{N}_{1}\left(100 \mathrm{~kg} \mathrm{~N} \mathrm{ha}^{-1}\right), \mathrm{N}_{2}\left(150 \mathrm{~kg} \mathrm{~N} \mathrm{ha}^{-1}\right)$ dan $\mathrm{N}_{3}\left(200 \mathrm{~kg} \mathrm{~N} \mathrm{ha}^{-1}\right)$. Hasil penelitian menunjukkan bahwa suhu, pemupukan $\mathrm{K}$ dan $\mathrm{N}$ berpengaruh terhadap tinggi tanaman, jumlah daun dan jumlah anakan. Pemupukan K $150 \mathrm{~kg} \mathrm{ha}^{-1}$ dan N $200 \mathrm{~kg} \mathrm{ha}^{-1}$ efektif untuk meningkatkan pertumbuhan tanaman padi inpari 30 pada suhu $33-37^{\circ} \mathrm{C}$.
\end{abstract}

Kata kunci: Pertumbuhan, Inpari 30, Suhu, Kalium, Nitrogen

\begin{abstract}
The purpose of this study was to determine the effect of temperature, $\mathrm{K}$ and $\mathrm{N}$ fertilization on the growth of Inpari 30 rice plants. This research was carried out in Greenhouse 1 and Greenhouse 2, Faculty of Agriculture, Syiah Kuala University which took place from November 2020 to February 2021. This study was conducted using the Split-split Plot design with factorial RBD pattern $2 \times 2 \times 3$ with 3 replications so that there were 12 treatment combinations and 36 experimental units with a total of 108 experimental units. The factors studied were temperature $(\mathrm{T})$ as the main plot consisting of two levels, namely $\mathrm{T}_{1}\left(28-32^{\circ} \mathrm{C}\right)$ and $\mathrm{T}_{2}\left(33-37^{\circ} \mathrm{C}\right)$, fertilization of $\mathrm{K}(\mathrm{K})$ as a subplot which consisted of two levels, namely $\mathrm{K}_{1}\left(100 \mathrm{~kg} \mathrm{~K} \mathrm{ha}^{-1}\right)$ and $\mathrm{K}_{2}(150 \mathrm{~kg} \mathrm{~K} \mathrm{ha}$ $\left.{ }^{1}\right)$. and fertilization of $\mathrm{N}(\mathrm{N})$ as subsubplots consisting of three levels, namely $\mathrm{N}_{1}\left(100 \mathrm{~kg} \mathrm{~N} \mathrm{ha}^{-1}\right), \mathrm{N}_{2}(150 \mathrm{~kg} \mathrm{~N}$ $\left.\mathrm{ha}^{-1}\right)$ and $\mathrm{N}_{3}\left(200 \mathrm{~kg} \mathrm{~N}^{-1}\right)$. The results showed that temperature, $\mathrm{K}$ and $\mathrm{N}$ fertilization had an effect on plant height, number of leaves and number of tillers. Fertilization of $\mathrm{K} 150 \mathrm{~kg} \mathrm{ha}^{-1}$ and $\mathrm{N} 200 \mathrm{~kg} \mathrm{ha}^{-1}$ was effective to increase the growth of Inpari 30 rice plants at a temperature of $33-37^{\circ} \mathrm{C}$.
\end{abstract}

Keywords: Growth, Inpari 30, Temperature, Potassium, Nitrogen

\section{PENDAHULUAN}

Padi (Oryza sativa L.) merupakan tanaman yang sangat dipengaruhi faktor ekologis dari fase bibit sampai panen (Ichsan et al., 2021a). Penanganan awal pada fase vegetatif sangat menentukan pertumbuhan tanaman (Ichsan et al., 2021b). Padi merupakan komoditi utama bagi sebagian besar penduduk di Indonesia. Hampir $90 \%$ dari penduduk Indonesia mengkonsumsi beras sebagai makanan pokok. Jumlah penduduk yang meningkat di setiap tahunnya sebanding dengan meningkatnya keperluan beras nasional, namun produksi nasional selama ini belum mampu memenuhi kebutuhan penduduk di Indonesia (Jamil et al., 2020). Permasalahan yang terjadi dalam upaya untuk meningkatkan produksi padi adalah besarnya persentase gabah hampa yang terjadi pada musim kering atau suhu tinggi. Cekaman 
lingkungan menjadi kendala dalam bercocok tanam padi yang menyebabkan penurunan pertumbuhan dan hasil (Ichsan et al., 2021c). Padi masih dapat mempertahankan pertumbuhan dengan normal pada suhu mulai dari $27^{\circ} \mathrm{C}$ hingga $32^{\circ} \mathrm{C}$ tanpa mengalami penurunan terhadap hasil gabah yang signifikan, namun pada suhu diatas $32^{\circ} \mathrm{C}$ berpengaruh negatif terhadap semua tahapan pertumbuhan dan perkembangan tanaman padi (Aghamolki et al., 2014). Menurut Ridha et al. (2018) perlakuan cekaman suhu mempengaruhi jumlah gabah malai $^{-1}$, persentase gabah berisi malai ${ }^{-1}$, persentase gabah hampa malai ${ }^{-1}$ serta berat gabah berisi malai ${ }^{-1}$.

Unsur hara dalam jumlah yang cukup adalah salah satu faktor pendukung agar tanaman dapat tumbuh dan memperoleh hasil yang optimal. Apabila unsur hara tidak tersedia dalam jumlah yang cukup di dalam tanah, maka dapat dilakukan pemupukan (Tando, 2018). Berdasarkan penelitian oleh Bahar (2014), pemberian kalium $100 \mathrm{~kg} \mathrm{ha}^{-1}$ dapat meningkatkan hasil padi karena memberikan pengaruh terhadap tinggi tanaman dan jumlah anakan. Berdasarkan penelitian oleh Nurmayulis et al. (2011) dan Anhar et al. (2016), pemberian pupuk nitrogen sebanyak $200 \mathrm{~kg} \mathrm{ha}^{-1}$ memberikan pengaruh terhadap tinggi tanaman, jumlah anakan, serta produksi dari tanaman padi.

Pemberian pupuk $\mathrm{N}$ menyebabkan peningkatan $\mathrm{N}$ yang tersedia sehingga meningkatnya jumlah asam amino yang terbentuk didalam bagian tanaman. Selanjutnya asam amino akan dirubah menjadi protein melalui proses biokimia yang komplek. Protein merupakan penyusun dari semua bagian tanaman, misalnya protoplasma dan kloroplas. Protein dan glukosa yang merupakan hasil dari proses fotosintesis akan membentuk sel-sel baru pada tanaman, dimana sel-sel baru ini kemudian akan membentuk jaringan-jaringan pada tanaman (Shanti, 2020).

Menurut Bahrami-rad et al. (2017) pemberian kalium dapat meningkatkan kandungan prolin. Kalium berfungsi untuk menjaga tekanan osmotik serta keseimbangan cairan atau air di dalam sel. Sintesis dan akumulasi senyawa osmolit berperan dalam pengaturan tekanan osmotik sel serta melindungi sel-sel dengan cara mengikat spesies oksigen reaktif (ROS) (Fayyaz et al., 2013). Berdasarkan uraian diatas maka perlu dilakukan penelitian pengaruh suhu, pemupukan $\mathrm{K}$ dan $\mathrm{N}$ terhadap pertumbuhan tanaman padi.

\section{METODE PENELITIAN}

\section{Tempat dan Waktu Penelitian}

Penelitian ini dilaksanakan di Rumah Kaca 1 dan Rumah Kaca 2 Fakultas Pertanian Universitas Syiah Kuala, Darussalam Banda Aceh. Penelitian berlangsung dari November 2020-Februari 2021.

\section{Alat dan Bahan}


Alat yang digunakan dalam penelitian ini adalah tray $(27,5 \mathrm{~cm}$ x $21 \mathrm{~cm})$, pot $(30 \mathrm{~cm} \mathrm{x}$ $35 \mathrm{~cm}$ ), cangkul, alat tulis, kertas label, lakban bening, meteran, gunting, penggaris, dan kamera HP.

Bahan yang digunakan dalam penelitian ini adalah benih padi varietas Inpari 30 yang diperoleh dari petani Gampong Jeureula, Lambaro Sibreh, Jalan Banda Aceh-Medan km 15, tanah entisol sebanyak $\pm 1080 \mathrm{~kg}$, pupuk kandang sapi, pupuk SP-36, pupuk urea dan pupuk $\mathrm{KCl}$.

\section{Analisis Data}

Analisa data menggunakan Rancangan Split-split Plot dengan pola RAK Faktorial 2x2x3 yang terdiri dari 3 faktor dan 3 kali ulangan. Data dianalisis dengan menggunakan annova, jika terdapat perbedaan nyata dari perlakuan maka selanjutnya dilakukan uji lanjut DNMRT pada taraf 5\%.

\section{Prosedur Pelaksanaan Penelitian}

\section{Perkecambahan benih dan persemaian}

Sebelum dikecambahkan, benih padi dibersihkan dengan cara dicuci sampai bersih dan direndam selama 1 x 24 jam didalam wadah. Kemudian ditiriskan dan dikecambahkan diatas wadah. Setelah berkecambah secara merata, benih dipindahkan ke tempat atau tray persemaian. Persemaian dilakukan 15 hari sebelum penanaman. Media persemaian terdiri dari campuran pupuk kandang sapi dan tanah entisol (1:2).

\section{Persiapan media tanam}

Tanah jenis entisol dimasukkan kedalam pot sebanyak $10 \mathrm{~kg} \mathrm{pot}^{-1}$, kemudian diberikan air sambil diaduk hingga bercampur rata dan menjadi seperti lumpur. Tanah dibiarkan sampai jenuh selama 14 hari.

\section{Penanaman}

Penanaman dilakukan dengan cara menugal pada kedalaman 3-4 cm ketika bibit berumur 15 HSS (hari setelah semai), sebaiknya dilakukan pada sore hari untuk mencegah stress pada bibit.

\section{Perlakuan suhu}

Terdapat dua perlakuan suhu, yaitu suhu $\mathrm{T}_{1}\left(28-32^{\circ} \mathrm{C}\right)$ dan $\mathrm{T}_{2}\left(33-37^{\circ} \mathrm{C}\right)$. Untuk perlakuan suhu $28-32^{\circ} \mathrm{C}$, tanaman padi diletakkan di Rumah Kaca 1 dari awal penanaman sampai waktu panen. Sedangkan untuk perlakuan suhu $33-37^{\circ} \mathrm{C}$, tanaman padi diletakkan di Rumah Kaca 2 dari awal penanaman sampai waktu panen. 


\section{Pemupukan}

Pemupukan dasar dilakukan dengan pemberian pupuk P sebanyak $150 \mathrm{~kg} \mathrm{ha}^{-1}$ (setara dengan 416,67 $\mathrm{kg} \mathrm{ha}^{-1} \mathrm{SP}-36$ ). Pemupukan K dan N dilakukan pada $7 \mathrm{HST}, 30 \mathrm{HST}$ dan 60 HST. Pemupukan K dilakukan dengan dosis $100 \mathrm{~kg} \mathrm{ha}^{-1}$ (setara dengan 166,67 kg ha-1 $\mathrm{KCl}$ ). Dosis $150 \mathrm{~kg} \mathrm{ha}^{-1}$ (setara dengan $250 \mathrm{~kg} \mathrm{ha}^{-1} \mathrm{KCl}$ ). Pemupukan $\mathrm{N}$ dilakukan dengan dosis 100 $\mathrm{kg} \mathrm{ha}^{-1}$ (setara dengan 217,39 $\mathrm{kg} \mathrm{ha}^{-1}$ urea). Dosis $150 \mathrm{~kg} \mathrm{ha}^{-1}$ (setara dengan 326,09 $\mathrm{kg} \mathrm{ha}^{-1}$ urea). Dosis $200 \mathrm{~kg} \mathrm{ha}^{-1}$ (setara dengan 434, $79 \mathrm{~kg} \mathrm{ha}^{-1}$ urea).

\section{Pemeliharaan tanaman}

Pemberian air dilakukan hingga panen dan air yang diberikan berasal dari air PDAM. Pengairan dan penggenangan pada awal pertumbuhan dilakukan dengan menjaga ketinggian muka air didalam pot setinggi $2,5 \mathrm{~cm}$ dari permukaan tanah sampai panen. Penyiangan gulma dilakukan secara manual setiap minggu.

\section{Pemanenan}

Panen dilakukan pada saat setiap malai tanaman dari suatu pot perlakuan sudah mencapai $90 \%$ gabah yang sudah menguning dan sulit dipecahkan dengan kuku.

\section{Parameter yang diamati}

Parameter yang diamati mengikuti SES (Standart Evaluation System for Rice) yang dikeluarkan oleh IRRI pada tahun 2002). Parameter yang diamati adalah sebagai berikut :

1. Tinggi Tanaman $(\mathrm{Cm})$

Diukur pada 30, 45 dan 60 HST, diukur dari permukaan tanah yang telah diberi tanda sampai ujung daun tertinggi (Saputra, 2016; Ichsan et al., 2021a).

2. Jumlah Daun (Helai)

Dihitung pada 30, 45 dan 60 HST pada masing-masing rumpun. Daun yang dihitung adalah daun yang telah membuka sempurna (Bustami, 2012).

3. Jumlah Anakan (Batang)

Dihitung anakan yang minimal mempunyai dua daun yang telah berkembang sempurna (Saputra, 2016), dilakukan pada 45 dan 60 HST pada masing-masing rumpun.

\section{HASIL DAN PEMBAHASAN}

\section{Tinggi tanaman}

Pemupukan mampu meningkatkan pertumbuhan pada fase vegetatif karena unsur nitrogen lebih banyak diserap oleh tanaman pada fase awal untuk meningkatkan pertumbuhan vegetatif seperti tinggi tanaman. Tinggi tanaman terbaik pada 45 HST dijumpai pada $\mathrm{T}_{2} \mathrm{~K}_{2} \mathrm{~N}_{3}$, hal ini membuktikan bahwa pemberian $\mathrm{K} 150 \mathrm{~kg} \mathrm{ha}^{-1}$ dan $\mathrm{N} 200 \mathrm{~kg} \mathrm{ha}^{-1}$ mampu meningkatkan pertumbuhan tinggi tanaman pada kondisi suhu tinggi. 


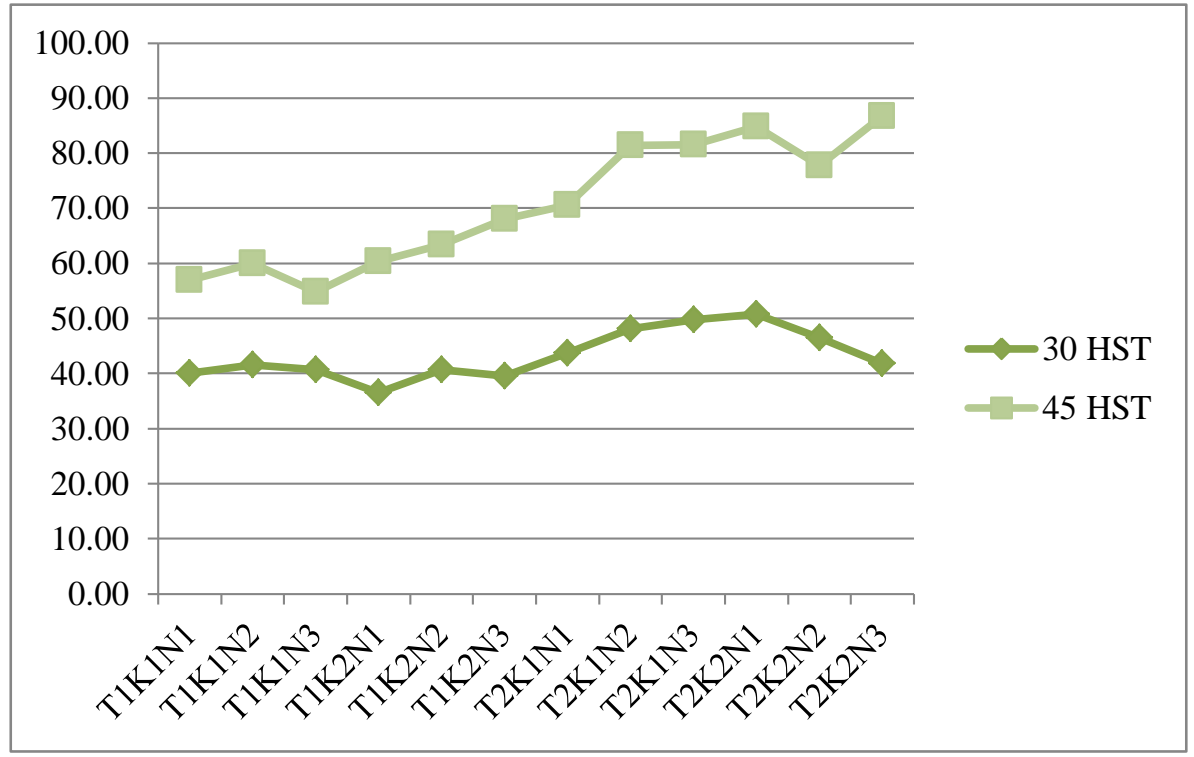

Gambar 1. Grafik Tinggi Tanaman 30 dan 45 HST akibat suhu, pemupukan K dan N

Sejalan dengan hasil penelitian Kaya (2014), pemberian kalium dan nitrogen dapat mempengaruhi pertumbuhan tinggi tanaman. Kalium berperan dalam proses fisiologis seperti pembelahan sel, merombak hasil fotosintesis menjadi protein dan mengatur kerja dari enzim. Hal ini sesuai dengan hasil penelitian Supartha et al. (2012), kalium berperan untuk menjaga turgor sel dan pupuk $\mathrm{N}$ berperan untuk membentuk protein pada saat pertumbuhan vegetatif.

Unsur hara kalium berperan dalam menjaga tekanan turgor sehingga proses metabolisme tanaman dapat berjalan lancar dan menjamin kesinambungan pemanjangan sel. Sejalan dengan hasil penelitian Abu et al. (2017), ketersediaan unsur $\mathrm{N}$ dalam yang jumlah yang sesuai dapat memacu pertumbuhan akar, memperlancar fotosintesis dan proses sintesis protein yang mendorong pertumbuhan tanaman pada fase vegetatif menjadi lebih optimal. Perubahan teknik pemupukan diperlukan untuk mengatasi pengaruh cekaman pada tanaman padi (Ichsan et al., 2021d).

\section{Jumlah Daun}

Jumlah daun terbaik pada 30 dan 60 HST dijumpai pada $\mathrm{T}_{2} \mathrm{~K}_{2} \mathrm{~N}_{3}$, hal ini membuktikan bahwa pemberian $\mathrm{K} 150 \mathrm{~kg} \mathrm{ha}^{-1}$ dan $\mathrm{N} 200 \mathrm{~kg} \mathrm{ha}^{-1}$ mampu meningkatkan jumlah daun tanaman padi pada kondisi suhu tinggi. Hal ini disebabkan oleh peran kalium dalam memperkuat batang tanaman sehingga jumlah daun yang dapat dihasilkan tanaman meningkat (Silahooy, 2008). Keseimbangan antara K dan N dapat meningkatkan jumlah daun. 


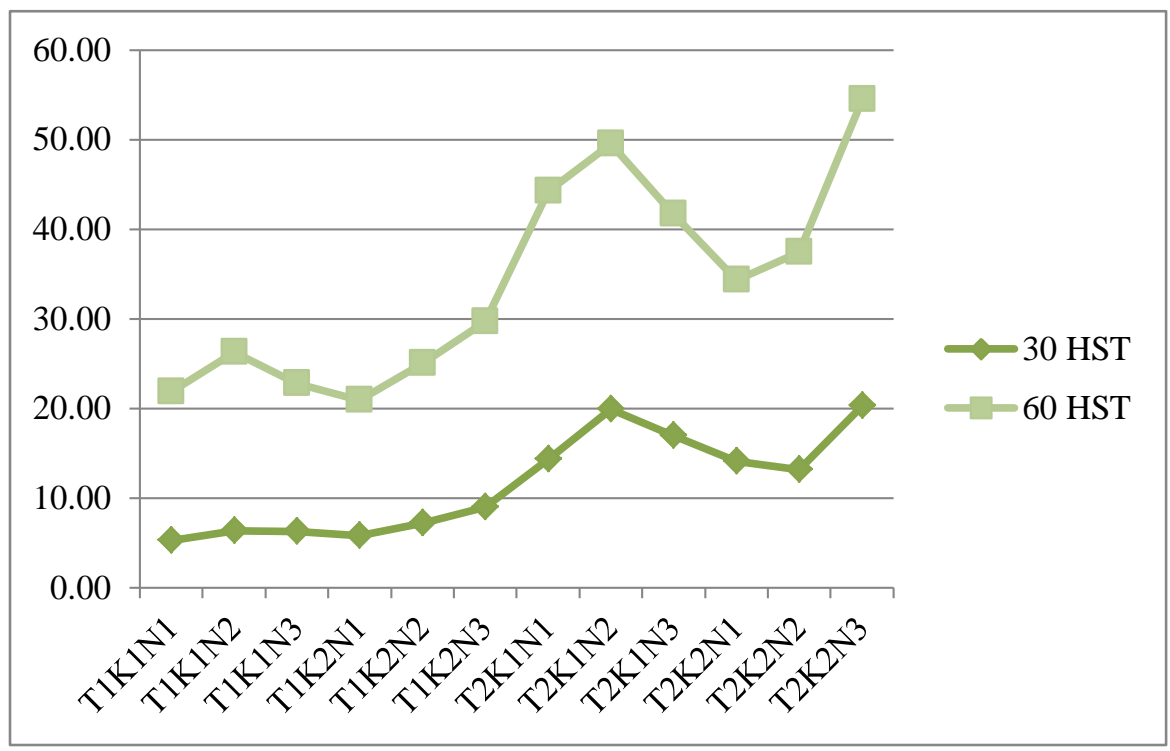

Gambar 2. Grafik Jumlah Daun 30 dan 60 HST akibat suhu, pemupukan K dan N

Sifat $\mathrm{N}$ dapat ditranslokasikan dari jaringan yang sudah tua menuju jaringan muda yang tumbuh aktif (Tando, 2018). Unsur $\mathrm{N}$ dapat mendorong pertumbuhan dan hasil tanaman padi salah satunya melalui peningkatan jumlah daun. Sejalan dengan hasil penelitian Widodo dan Damanhuri (2021), nitrogen merupakan bagian dari hormon auksin yang digunakan oleh tanaman pada saat melakukan pembelahan dan pemanjangan sel. Peningkatan pemanjangan dan pembelahan sel akan menyebabkan peningkatan jumlah daun yang terbentuk.

Sejalan dengan hasil penelitian Fitriani et al. (2019), unsur K dan $\mathrm{N}$ mampu meningkatkan serapan hara dari dalam tanah karena dapat mempengaruhi perkembangan akar sehingga dapat meningkatkan jumlah daun tanaman padi. Jumlah daun yang mampu dihasilkan tanaman padi meningkat dengan adanya pemberian unsur hara kalium. Peningkatan kalium diperlukan untuk meningkatkan jumlah daun. Sejalan dengan hasil penelitian Ichsan et al., (2021c,d). perkembangan akar padi sangat dipengaruhi oleh lingkungan. Pada lingkungan tercekam diperlukan pemberian kalium yang berperan dalam sintesis karbon hidrat, seperti gula yang berperan sebagai osmolit pada kondisi tercekam (Ichsan et al., 2021c). Hal ini disebabkan oleh peran kalium sebagai makronutrien yang diperlukan tanaman untuk pertumbuhan, perkembangan maupun hasil yang optimal. Sejalan dengan hasil penelitian Kazemi (2014), kalium dibutuhkan tanaman untuk mendorong pertumbuhan dan perkembangan tanaman.

Alibu and Mamadou (2021) menyatakan bahwa nitrogen dibutuhkan tanaman dalam jumlah yang relatif besar. Nitrogen merupakan komponen pembentuk klorofil yang berperan penting dalam pembentukan asam amino dan protein. Klorofil berfungsi untuk menyerap sinar matahari dan menggunakannya untuk mensintesis karbohidrat. Asam amino dirubah menjadi protein yang akan dimanfaatkan tanaman untuk mengontrol pertumbuhan. Hal ini 
menunjukkan bahwa tanaman menyerap unsur hara untuk mengoptimalkan pertumbuhan daun sehingga pemberian kalium dan nitrogen yang berimbang akan meningkatkan jumlah daun 30 dan 60 HST.

\section{Jumlah Anakan}

Jumlah anakan terbaik pada 45 HST dijumpai pada $\mathrm{T}_{2} \mathrm{~K}_{2} \mathrm{~N}_{3}$, hal ini membuktikan bahwa pemberian $\mathrm{K} 150 \mathrm{~kg} \mathrm{ha}^{-1}$ dan $\mathrm{N} 200 \mathrm{~kg} \mathrm{ha}^{-1}$ mampu meningkatkan jumlah anakan tanaman padi pada kondisi suhu tinggi.

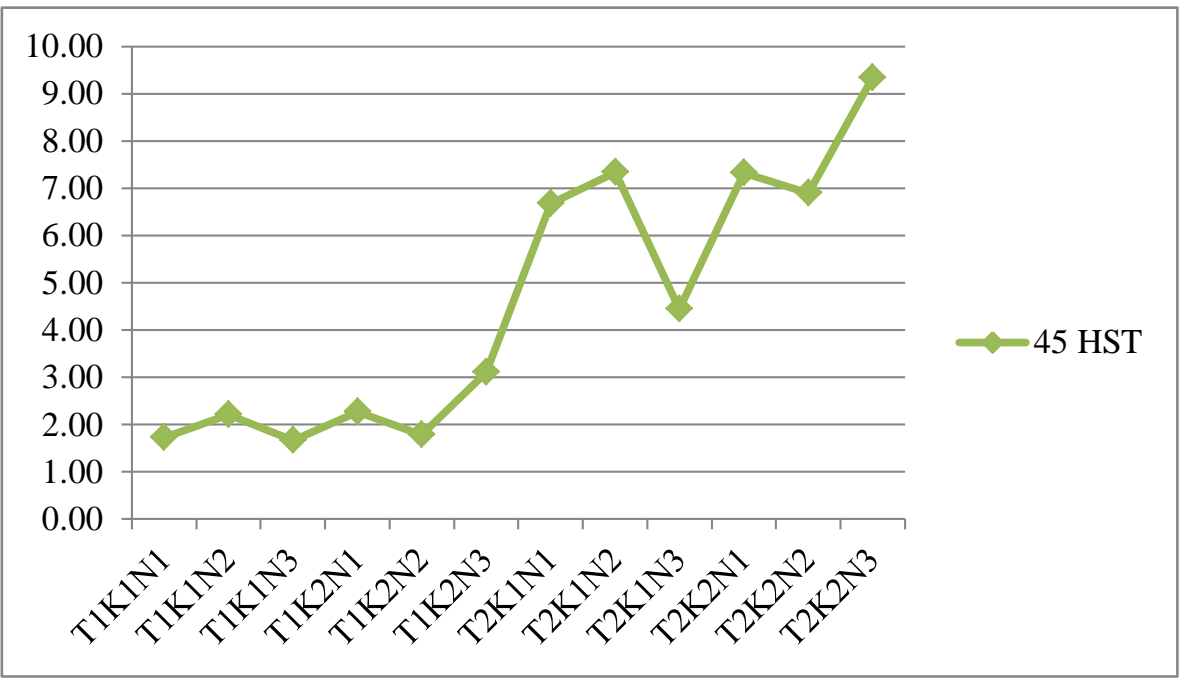

Gambar 3. Grafik Jumlah Anakan 45 HST akibat suhu, pemupukan K dan N

Peningkatan suhu menyebabkan peningkatan transpirasi yang diikuti dengan peningkatan serapan hara. Peningkatan serapan hara menyebabkan peningkatan kapasitas metabolisme seperti fotosintesis yang hasilnya merupakan bahan baku untuk pembentukan sel baru yang menjadi dasar pembentukan anakan. Penelitian Aghamolki et al. (2014) menunjukkan bahwa cekaman suhu tinggi menyebabkan tanaman menghasilkan anakan lebih banyak sebagai cara untuk menyesuaikan diri dengan lingkungannya sehingga dapat menurunkan suhu udara disekitar tanaman. Tanaman mempunyai mekanisme untuk mengatasi cekaman (Ichsan et al., 2021e).

Kenaikan suhu di siang hari mampu mempengaruhi pertumbuhan anakan, pengembangan luas daun dan pemanjangan batang tanaman padi. Kalium berperan dalam menghasilkan prolin yang berfungsi sebagai osmoprotektan bagi tanaman dalam menghadapi cekaman lingkungan seperti suhu tinggi (Kurnia dan Suprihati, 2013). Berdasarkan penelitian Faozi dan Wijonarko (2010) dan Azalika et al. (2018), pupuk N berperan dalam pembentukan dan meningkatkan jumlah anakan. Berdasarkan hasil penelitian Widodo dan Damanhuri (2021), nitrogen berperan penting dalam pembentukan anakan karena $\mathrm{N}$ 
merupakan komponen pembentukan hormon dan enzim yang berperan dalam membentuk pertunasan padi.

\section{KESIMPULAN}

Pemberian K $150 \mathrm{~kg} \mathrm{ha}^{-1}$ dan $\mathrm{N} 200 \mathrm{~kg} \mathrm{ha}^{-1}$ dapat meningkatkan pertumbuhan tinggi tanaman, jumlah daun dan jumlah anakan tanaman padi untuk padi Inpari 30 yang ditanam dengan sistem genangan $2 \mathrm{~cm}$ dari awal penanaman.

\section{DAFTAR PUSTAKA}

[IRRI] International Rice Research institute. 2002. Rice Almanac. Source Book for the Most Important Economic Activity on Earth. International Rice Research institute. Metro Manilla, Philippines. 257 p.

Abu, R.L.A., Basri, Z. dan Made, U., 2017. Respon Pertumbuhan dan Hasil Tanaman Padi (Oryza sativa L.) terhadap Kebutuhan Nitrogen Menggunakan Bagan Warna Daun. $J$. Agrolang, 24(2), pp.119-127.

Aghamolki, M.T.K., Yusop, M.K., Oad, F.C.H., Zakikhani, H.Z., Jaafar, S. and Kharidah., 2014. Heat Stress Effects on Yield Parameters of Selected Rice Cultivars at Reproductive Growth Stages. J. Food Agric, Environ. 12, pp.741-746.

Alibu, S and Mamadou. F., 2021. How does Water Stress and Nitrogen Fertilizer Affect the Growth and Yield of Upload Rice (Oryza sativa L.). Journal of Food and Nutrition Research, 9(4), pp.215-222.

Anhar, R., Hayati, E. dan Efendi., 2016. Pengaruh Dosis Pupuk Urea terhadap Pertumbuhan dan Produksi Plasma Nutfah Padi Lokal asal Aceh. Jurnal Kawista, 1(1), pp.30-36.

Azalika, R.P., Sumardi dan Sukisno., 2018. Pertumbuhan dan Hasil Padi Sirantau pada Pemberian beberapa macam dan Dosis Pupuk Kandang. Jurnal Ilmu-Ilmu Pertanian Indonesia, Fakultas Pertanian Universitas Bengkulu, Bengkulu.

Bahar, E., 2014. Pertumbuhan dan Hasil Padi Gogo Varietas Tondano pada Pemberian Zat Pengatur Tumbuh dan Pupuk Kalium (Oryza sativa L.). Jurnal sungkai, 2(1), pp.10-22.

Bahrami-rad, Sara and Hajiboland, R., 2017. Effect of Potassium Application in Droughtstressed Tobacco (Nicotiana rustica L.) Plants: Comparison of Root with Foliar Application. Annals of Agricultural Science, 62, pp.121-130.

Bustami., Sufardi. dan Bakhtiar., 2012. Serapan Hara dan Efisiensi Pemupukan Phosfat serta Pertumbuhan Padi Varietas Lokal. Jurnal Manajemen Sumberdaya Lahan, 1(2), pp.159170.

Faozi, K. dan Wijonarko, B.R., 2010. Serapan Nitrogen dan Berbagai Sifat Fisiologi Tanaman Padi Sawah dari Berbagai Umur Pemindahan Bibit. Jurnal Pembangunan Pedesaan, 10(2), pp.93-101. 
Fayyaz, P., Etemadi, E., Julaiee-Manesh N and Zolfaghari, R., 2013. Sodium and Potassium Allocation under Drought Stress in Atlas Mastic Tree (Pistacia atlantica sub sp. Mutica). Journal of Biogeosciences and Forestry, 6, pp.90-94.

Fitriani., Fajar, B.A., Putri, K.A. dan Persada, A.Y., 2019. Analisis Karakter Morfologi Tanaman Padi yang diaplikasikan dengan Silika dan Kalium organik. Jurnal Jeumpa, 6(2), pp.277-286.

Ichsan, C. N. 2021a. Morphological and physiological change of rice (Oryza sativa L.) under water stress at early season. In IOP Conference Series: Earth and Environmental Science (Vol. 644, No. 1, p. 012030). IOP Publishing.

Ichsan, C. N. 2021b. Morpho-agronomic traits and balance of sink and source of rice planted on upland rainfed. In IOP Conference Series: Earth and Environmental Science (Vol. 667, No. 1, p. 012108). IOP Publishing.

Ichsan, C. N. 2021c. Perubahan karakter morfo-agronomis dan fisiologis tanaman padi (oryza sativa 1.) Pada kondisi stres air. Disertasi. Universitas Syiah Kuala. Banda Aceh, Indonesia

Ichsan, C. N., Basyah, B., Zakaria, S., \& Efendi, E. 2021d. Alteration of dry matter accumulation under soil moisture fluctuation stress in rice (Oryza sativa L.). AJCS 15(05), 757-763

Ichsan, C. N., Sulaiman, M. I., \& Andini, R. 2021e. Role of plant genetic resources in encountering climate change challenge. In IOP Conference Series: Earth and Environmental Science (Vol. 711, No. 1, p. 012008). IOP Publishing.

Jamil, H., Zainal., Yunus, M., Baharuddin. dan Tuwo, M., 2020. Aplikasi Pupuk Hayati Mikrobat untuk Meningkatkan Produktivitas Pertanaman Padi Desa Bulu Allaporenge Kabupaten Bone. Jurnal Ilmu Alam dan Lingkungan, 11(1), pp.10-15.

Kazemi, M., 2014. Effect of Gibberellic Acid and Potassium Nitrate Spray on Vegetative Growth and Reproductive Characteristics of Tomato. Journal of Biological and Environmental Sciences, 8(22), pp.1-9.

Kurnia, T.D. dan Suprihati., 2013. Prolin sebagai Penanda Ketahanan Kekeringan dan Salinitas pada Gandum. ResearchGate, pp.1-8.

Nurmayulis, P., Utama, D., Firnia,. dan Yani, H., 2011. Respons Nitrogen dan Azolla terhadap Pertumbuhan Tanaman Padi Varietas Mira I dengan Metode SRI. Jakarta, pp.115-129.

Ridha, R., Siregar, D.L. dan Marnita, Y., 2018. Tingkat Ketahanan Plasma Nutfah Padi Gogo (Oryza sativa L.) Lokal Aceh Pada Cekaman Suhu Tinggi Selama Fase Reproduktif. Jurnal Penelitian Agrosamudra, 5(2), pp.61-69.

Saputra, I., 2016. Efek Dosis Pupuk Nitrogen dan Varietas Terhadap Efisiensi Pemupukan, Serapan Hara N dan Pertumbuhan Padi Lokal Aceh Dataran Rendah. Jurnal Penelitian Agrosamudra, 3(2), pp.61-71. 
Shanti, R., 2020. Pertumbuhan dan Produksi Padi (Oryza sativa) Pengaruh Pengapuran dan Pemupukan Pada Ultisol. Jurnal Agroekoteknologi Tropika Lembab, 2(2), pp.99-104.

Silahooy., 2008. Efek Pupuk KCl dan SP-36 Terhadap Kalium Tersedia, dan Serapan Kalium Pada Tanah Brunizem. Bul. Agron, 36(2), pp.126-132.

Supartha, I.N.Y., Wijana, G. dan Adnyana, G.M., 2012. Aplikasi Jenis Pupuk Organik Pada Tanaman Padi Sistem Pertanian Organik. E-Jurnal Agroteknologi Tropika, 1(2), pp.98106.

Tando, E., 2018. Upaya Efisiensi dan Peningkatan Ketersediaan Nitrogen dalam Tanah serta Serapan Nitrogen Pada Tanaman Padi Sawah (Oryza Sativa L.). Buana Sains, 18(2), pp.171-180.

Widodo, T.M. dan Damanhuri., 2021. Pengaruh Dosis Nitrogen terhadap Pembentukan Tunas dan Pertumbuhan Padi Ratun (Oryza sativa L.). Jurnal Ilmiah Inovasi, 21(1), pp.50-53. 